\title{
Constraints and trade-offs in climate-dependent adaptation: energy budgets and growth in a latitudinal cline*
}

\author{
HANS O. PÖRTNER, DANIELA STORCH and OLAF HEILMAYER \\ ${ }^{1}$ Alfred-Wegener-Institut für Polar- und Meeresforschung, Ökophysiologie, 27515 Bremerhaven, Germany. \\ E-mail: hpoertner@awi-bremerhaven.de
}

\begin{abstract}
SUMMARY: Characteristics of temperature-dependent metabolic adaptation as well as their implications for associated changes in energy budgets are analysed based on comparisons of fish and invertebrates from various latitudinal clines in northern and southern hemispheres and on integrated ecological and physiological approaches. To identify putative "bottlenecks" of adaptation and for a general cause and effect understanding, the temperature sensitivity of growth as a key energy budget component is investigated, considering underlying processes at population, whole animal and cellular levels. Available data support the hypothesis that natural selection favours individuals for energy efficiency and maximised growth, but is subject to constraints of limited energy availability and temperature. According to emerging relationships between energy turnover, temperature variability and thermal tolerance, the notion that selection should favour a certain metabolic rate according to mean temperature is too simplistic. Within the energy budget, savings in maintenance costs set free energy for growth, visible as growth increments at a low standard metabolic rate. Such energy savings are maximised at the permanently low temperature of the Antarctic. However, some variability persists as pelagic lifestyles in the Antarctic are fuelled by higher metabolic rates at the expense of reduced growth. Temperature variability in the cold, as in the Subarctic, causes a rise in maintenance costs at the expense of growth, but in favour of exercise and thus foraging capacity. Such transitions in energy cost between sub-polar and polar areas are not visible in the southern hemisphere, where there is less temperature variability. However, these patterns - as well as many of the underlying mechanisms - still remain incompletely investigated, especially with respect to the suggested hierarchy in energy allocation to energy budget components.
\end{abstract}

Keywords: Antarctic, energy efficiency, lifestyle, cold adaptation, growth performance, Magellan, temperature variability, eurythermy, stenothermy.

RESUMEN: RESTRICCIONES Y BALANCES EN LA ADAPTACIÓN DEPENDIENTE DEL CLIMA: PRESUPUESTOS ENERGÉTICOS Y CRECIMIENTO EN UN GRADIENTE LATITUDINAL. - Las características de la adaptación metabólica dependiente de la temperatura y sus implicancias en los cambios asociados a los presupuestos energéticos son analizadas sobre la base de: comparaciones de peces e invertebrados de varios gradientes latitudinales en los hemisferios septentrional y meridional, y de enfoques ecológicos y fisiológicos integrados. Para identificar los "cuellos de botella" putativos de la adaptación y para un entendimiento general de la causa-efecto, se investiga la sensibilidad del crecimiento a la temperatura como un componente clave del presupuesto energético, considerando los procesos subyacentes a niveles poblacional, individual (animal completo) y celular. Los datos disponibles sostienen la hipótesis que la selección natural favorece a los individuos con eficiencia energética y crecimiento maximizado, pero es sujeto de restricciones por la limitada disponibilidad energética y la temperatura. De acuerdo a las relaciones emergentes entre el intercambio energético, variabilidad de temperatura y tolerancia térmica, la noción acerca de que la selección debería favorecer ciertos niveles de tasas metabólicas de acuerdo con la temperatura promedio es demasiado simplista. Dentro del presupuesto energético, los ahorros en costos de mantenimiento liberan energía para crecimiento, visible como incrementos de crecimiento a tasas metabólicas estándar bajas. Tales ahorros energéticos son maximizados a las permanentes bajas temperaturas de la Antártida. No obstante, algo de variabilidad persiste en tanto estilos de vida pelágicos en la Antártida son sustentados por tasas metabólicas relativamente más altas a expensas de crecimiento reducido. La variabilidad de temperatura ambientes fríos, como en el boreal, causa un incremento en los costos de mantenimiento a expensas del crecimiento, pero a favor del movimiento y por tanto la capacidad de forrajeo. Tales transi- 
ciones en el costo energético entre áreas polares y subpolares no son detectables en el hemisferio sur, donde la variabilidad de temperatura es menor. Sin embargo, estos patrones como tantos otros mecanismos subyacentes todavía permanecen incompletamente investigados, especialmente con respecto a la jerarquía sugerida en la distribución energética y componentes de los presupuestos energéticos.

Palabras clave: Antártida, eficiencia energética, formas de vida, adaptaciones al frío, eficiencia del crecimiento, Magallanes, variabilidad de temperatura, euritermia, estenotermia.

\section{INTRODUCTION}

Animals, due to their inherently high levels of organisational complexity, specialise in environmental temperature much more than unicellular bacteria and algae (Pörtner, 2002a). Accordingly, thermal tolerance windows differ between ectothermal animal species (with body temperatures determined by ambient values) - and sometimes their populations - depending on latitude or seasonal temperature variation. They are therefore related to geographical distribution (e.g. Roy et al., 1998; Pörtner, 2001, 2002a,b; Clarke, 2003). A consistent picture of how thermal tolerance windows develop between tropical and polar latitudes does not exist. There is, however, some evidence that towards colder regions/higher latitudes these patterns differ between northern and southern hemispheres; trends may follow the largely different patterns of temperature variability in the two hemispheres (Gaston and Chown, 1999; Pörtner, 2004). Trying to understand the limits and benefits of thermal specialisation, as well as their consequences for energy turnover, requires an understanding of the trade-offs and constraints in thermal adaptation. These become visible when temperature-dependent physiological characters are compared in ectotherms specialised in various temperature regimes. The marine realm, on a global scale, offers clearly defined thermal niches and, thus, an ideal basis for such comparisons. Marine animals of the high Antarctic - and possibly the deep sea-for example, rely on constant water temperatures. They include (possibly life's only) permanent stenotherms which are unable to sustain the complete set of life functions required for species survival and fitness at temperatures above 1 to $6^{\circ} \mathrm{C}$ (Pörtner et al., 1999a; Peck, 2002).

In this context, the principle physiological factors that cause animals to undergo thermal specialisation on evolutionary time scales need to be identified. What are the benefits of specialising in a narrow window of thermal tolerance, especially in the cold or, alternatively, what has forced Antarctic ectotherms into stenothermy? Why would the levels of stenothermy or eurythermy correlate at least roughly with the ambient temperature regime? There is a need to address the way in which higher functions such as foraging activity, growth and reproduction, which mainly shape the lifestyle and survival of a species in its natural environment, are affected by temperature and temperature-dependent energy turnover. More specifically, how much energy out of its energy budget can the animal make available to each of these functions, and is this process of energy allocation subject to temperaturedependent constraints?

A key question is what are the ecological benefits that are primarily selected for depending on ambient temperature? The present study sets out to investigate to what extent the level of energy turnover (measured as standard metabolic rate, SMR) and the energy budget, i.e. energy allocation to growth, reproduction or foraging activity, are affected by environmental temperature as well as by the climate-dependent mode of life. In this case, we focus on growth rate (the absolute rate of new tissue production), considering aspects of growth efficiency (the fraction of energy converted to new tissue; Clarke, 1987). The integrated analysis of the ecological and physiological literature in fact illustrates how selection acts differently on the different components of the energy budget according to the climate regime. For data interpretation we consider recently established physiological principles of thermal tolerance windows and the key mechanisms of thermal adaptation and limitation. To identify putative "bottlenecks" and for a general cause and effect understanding, the thermal sensitivity of key energy budget components is addressed at population, whole animal and cellular levels. It should be noted that the rate of standard metabolism usually reported in the literature includes all physiological processes operative in the post-absorptive resting but non-dormant organism. These estimates usually also include processes associated with growth, although these may contribute to variable degrees, depending on the physiological status of the individual specimen. 
The symposium theme is concerned with the separation and transition between Subantarctic and Antarctic realms. Since very little information is available for Subantarctic species, physiological answers for this special question can only be given once the general principles are known. The present study will therefore draw on examples from the Antarctic and temperate zones, as well as from the Subarctic where more detailed but still patchy knowledge is available. After describing some general principles it will then address the question of how these principles might apply to Subantarctic organisms and what specific research questions should be addressed in the future.

\section{Antarctic lifestyles, energy turnover and thermal windows}

The setting of thermal tolerance windows by the limited capacity of oxygen supply mechanisms emerges as a unifying principle across aquatic animal phyla (Pörtner, 2001, 2002a). For Antarctic species there is a need to consider why thermal windows differ between species (Pörtner et al., 2000). Critical temperatures range between 2 and $3^{\circ} \mathrm{C}$ in the bivalve Limopsis marionensis and, more commonly, 6 to $10^{\circ} \mathrm{C}$ in other Antarctic bivalves, octopods or fish (Pörtner and Zielinski, 1998, Pörtner et al., 1999a, 2000; Peck et al., 2002; Peck, 2002). Even higher critical temperatures exist in the limpet Nacella concinna, enabling this species to enter the intertidal zone (Pörtner et al., 1999a), and in the bivalve Yoldia eightsi, which carries out long digging excursions in the sediment to feed on deposits (Abele et al., 2001).

A preliminary comparison of the lifestyles of these species suggests that exclusively sessile epifauna species like Limopsis marionensis (Pörtner et al., 1999a) and Liothyrella uva (Peck et al., 1987a,b) are characterised by lower critical temperatures than more mobile species. In general, a decrease in aerobic scope and thus functional capacity occurs as a first line of thermal sensitivity even before critical temperatures are reached (Pörtner, 2001, 2002a). This emphasises "heat" limitation at even lower temperatures and thus the level of extreme stenothermy in at least some Antarctic species, leading to an early loss of performance (Urban, 1998; Peck et al., 2004). In addition, the capacity of oxygen provision by ventilation and circulation is likely to be higher in active fish or octopods than in mussels. This may explain the lower heat sensitivity in more mobile compared to sessile Antarctic species. In conclusion, the level of stenothermy among Antarctic species is probably co-defined by their level of agility and exercise capacity.

The historical concept of metabolic cold adaptation used to explain early findings of relatively high metabolic rates in Antarctic fish (Scholander et al., 1953; Wohlschlag, 1964) has been disproved by more recent measurements of oxygen uptake in a number of Antarctic and Arctic invertebrates and fish under relatively stress-free conditions (Holeton, 1974; Ralph and Maxwell, 1977a,b; Peck et al., 1987a; Chapelle and Peck, 1999; Whiteley et al., 1996; Pörtner et al., 1999a; van Dijk et al., 1999; Clarke and Johnston, 1999; Marsh et al., 2001; Heilmayer and Brey, 2003). It is now rather well established that the narrow thermal tolerance windows of Antarctic marine ectotherms go hand in hand with low resting or standard metabolic rates, and thus with lower costs of living than in warmer waters (Clarke and Johnston, 1999; Peck and Conway, 2000; Pörtner et al., 2000). This statement is true especially for those benthic Antarctic invertebrates with the lowest activity levels and the narrowest windows of thermal tolerance.

\section{Trade-offs in cold adaptation: stenotherms vs. eurytherms}

Cold-induced hypometabolism in Antarctic stenotherms correlates, on average, with reduced net aerobic scopes for exercise and thereby reduces the flexibility to respond to ambient temperature fluctuations resulting in narrow windows of thermal tolerance (see Pörtner, 2002a, b, for review). The opposite is the case in cold-adapted eurytherms, as seen in animals from northern hemisphere temperate and Subarctic zones, which tolerate wider temperature fluctuations and are able to dynamically shift or change the widths of tolerance windows in accordance with seasonal temperature fluctuations. Adaptation to cold but unstable temperatures comes at a high cost during both seasonal and latitudinal cold (e.g. Pörtner et al., 2000; Sokolova and Pörtner, 2003; Sommer and Pörtner, 2002, 2004; Sartoris et al., 2003; Pörtner, 2004). High SMRs found in cold-adapted and cold-acclimated eurytherms extend to enhanced capacities of ventilation and circulation as a precondition for widened windows of thermal tolerance, and as a consequence they support cold-compensated metabolic scopes and activity levels, i.e. enhanced aerobic scopes for exercise in cold-adapted eurytherms (Pörtner, 2002b). A 
comparison of the contrasting trends of stenothermal versus eurythermal cold adaptation would already suggest that the capacity of aerobic exercise may not primarily be selected for but may rather follow passively the climate-dependent setting of aerobic energy turnover (cf. Pörtner, 2004).

\section{MACRO-ECOLOGICAL AND MACRO- PHYSIOLOGICAL PATTERNS}

According to the above, the level of energy turnover depends on climate-dependent temperature oscillations, especially in the cold, and plays an important role in the setting of thermal tolerance windows and fitness in ectothermal animals. Within these general constraints natural selection should favour those individuals which are energy efficient, grow fast and reproduce successfully. Natural selection should therefore operate at all (molecular to organismal) levels of animal energetics, finally including maintenance, growth and reproductive activity. The levels of these processes are interdependent as they all take a share in the organism's energy budget. Hence, the fitness of an organism (i.e. growth and reproductive success) depends on energy turnover and is largely influenced by temperature and its variability.

In various climates, depending on temperature variability the vast array of structural and physiological adjustments required for counteracting the reduction in chemical reaction rates at low temperature may only be possible in certain ways to ensure matching of energy production and consumption (cf. Pörtner et al., 2005). These patterns will influence energy availability for growth and reproduction. Many of the underlying mechanisms still remain incompletely investigated (Zielinski and Pörtner, 1996; Guderley et al., 1997; Pörtner et al., 1998; Frederich and Pörtner, 2000; Peck et al., 2002; Pörtner, 2002a, b; Sommer and Pörtner, 2002, 2004; Hochachka and Somero, 2002). As a contribution the present chapter attempts to identify large-scale patterns that may be shaped by these mechanisms. More specifically, it essentially focuses on how the relationship between metabolic costs and growth may change depending on latitude.

\section{Growth patterns and energy turnover}

In principle, there are two ways to enhance growth of an ectothermal organism depending on the temperature regime and on resource availability in its natural environment. Firstly, growth can be maximised by minimising energy expenditure for maintenance or activity, especially under conditions in which nutrient supply and assimilated energy are limited. This principle has been verified in various aquatic and terrestrial ectotherm species from different phyla, including marine molluscs (within species: Koehn and Shumway, 1982; Hawkins and Day, 1996), freshwater fish (within species: Wieser and Medgyesy, 1991), amphibians (within species: Mitton et al., 1986) and reptiles (within species: Steyermark, 2002).

Alternatively, growth is maximised in high energy turnover life forms (e.g. among cephalopods or among endotherms in general) when selection for increased energy turnover and food conversion leaves excess energy for growth (cf. Pörtner, 2004). Such patterns may result from phylogenetic constraints in which, as among cephalopods, competition with vertebrates enforces a high energy turnover life associated with a high maintenance metabolism and growth (Pörtner et al., 1995). Within species or phyla such evolutionary patterns may be supported by the selection for high energy turnover under the precondition of excess resource availability (Mueller and Diamond, 2001). Such selection is probably enforced by climate variability (Pörtner, 2004).

Climate variability and resource availability may also shape latitudinal patterns. In a system like the Antarctic, animal life may be food-limited and growth is periodic in those species relying on the extremely seasonal primary production (Arntz et al., 1994, Clarke and Leakey, 1996; Brockington et al., 2001; Clarke, 2003). Based on an extensive review of the existing literature, Brey (1999) showed that mean annual growth rates are low in high-latitude invertebrates. Under favourable circumstances, however, growth performance of some polar species can approach those of temperate or even tropical species of similar size and ecology. It is most likely that under such conditions energy is primarily allocated to the growth component of the energy budget, at the expense of energy savings in the maintenance metabolism. These savings may, however, affect the functional capacity of other processes like muscular activity, and are one reason why the activity component of metabolism is reduced in Antarctic stenotherms. In fact, the observations that net aerobic scopes are low and that there are no high-performance predators in the Antarctic would suggest such 
a common constraint on Antarctic lifestyles (cf. Clarke, 1998; Pörtner, 2002b). Long-term evolutionary adaptation to the very cold and stable environmental temperatures of the Antarctic may have supported the maximisation of energy efficiency, characterised by a low basal metabolism. This would contrast with the cold eurythermal, more cost-intensive form of cold tolerance found in Subarctic and Arctic species of the northern hemisphere (Pörtner, 2002b; Lannig et al., 2003; Sartoris et al., 2003).

\section{Growth patterns in stenothermal and eurythermal fish}

Previous work in eurythermal cod and eelpout, which are cold-acclimated or cold-adapted in a latitudinal cline of the northern hemisphere, suggested that the rising cost of maintenance in eurytherms occurs at the expense of a reduction in temperaturespecific growth performance or in reproduction (Pörtner et al., 2001). At the same time high levels of baseline energy turnover and of metabolic capacity associated with eurythermal cold adaptation are suitable to support enhanced exercise capacity (Pörtner, 2002b). Trade-offs result between exercise capacity and growth performance, which may be shifted to lower growth performance in Arctic compared to temperate eurytherms (see Fig. 1).

Similar trade-offs are probably operative within Antarctic notothenioid fish. A recent overview of age and growth in high Antarctic notothenioid fish revealed an overall increase in growth performance from pelagic to benthic lifestyles (La Mesa and Vacci, 2001). The common ecological index of "overall growth performance (OGP)" $P$ (Pauly, 1979 , for review Brey, 2001) is used to compare growth between populations or species. $P$ is defined as the maximum rate of body mass increase during lifetime, i.e. the mass increment at the inflexion point of the Van Bertalanffy Growth Function which describes growth in body mass (for a detailed discussion see Vakily, 1992; Brey 2001). A comparison of $P$ values with the levels of SMR in Figure 2 confirms that slow growth goes hand in hand with high SMR in high Antarctic Notothenioid fish.

Only a few nototheniids, such as Pleurogramma antarcticum and Pagothenia borchgrevinki, have successfully invaded the midwater (Clarke and Johnston, 1996; La Mesa and Vacci, 2001). Pelagic Antarctic fish species experience extreme seasonality of light and food availability, reflecting an addi-

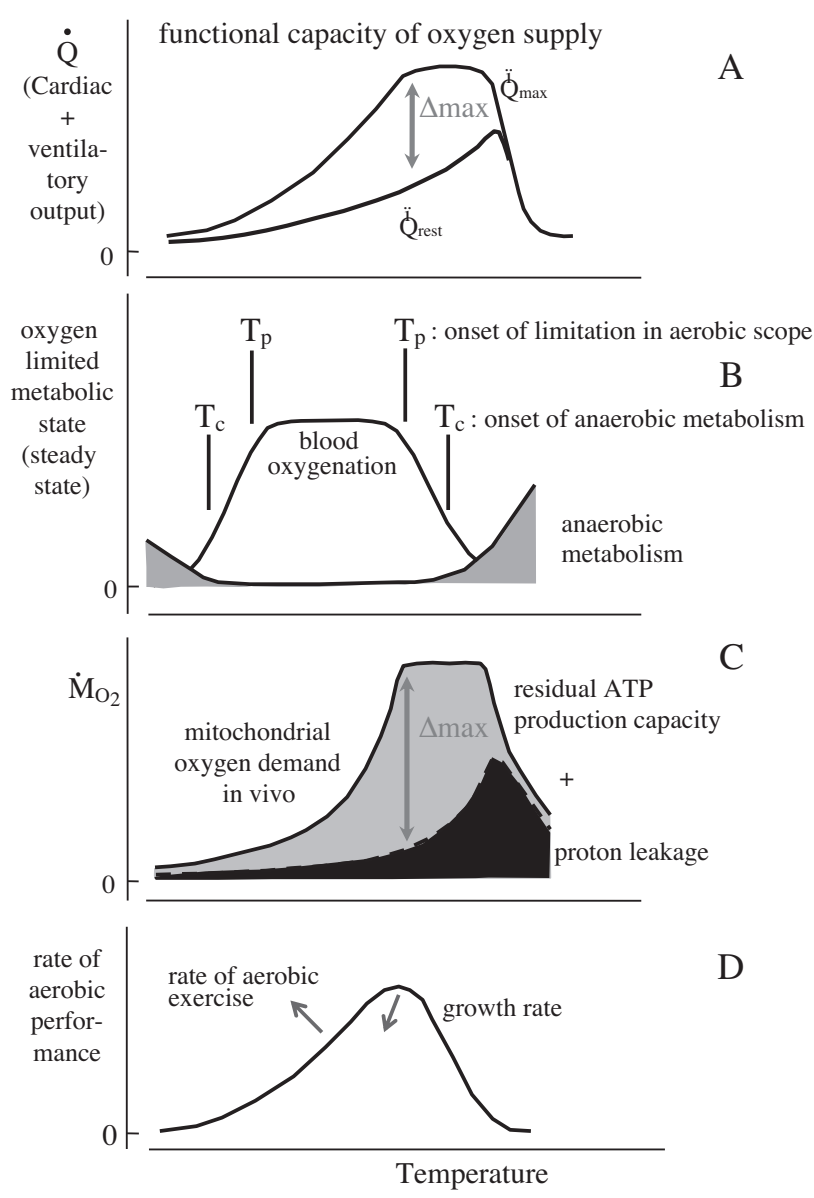

FIG. 1. - Schematic model of oxygen-limited thermal tolerance and performance capacity in fish and other metazoa, set by the capacity of oxygen supply mechanisms (adopted from Pörtner et al., 2004). (A) Functional reserves in oxygen supply result as combined ventilatory and cardiac output $(\mathrm{Q})$ and are maximum at the upper pejus temperature $\mathrm{Tp}$, before aerobic scope becomes thermally limited (B). Maximum scope $(\Delta \max )$ between resting and maximum output in oxygen supply is probably correlated with the one in mitochondrial ATP generation which is limited by oxygen supply in vivo (C). Low ATP formation capacity in the cold and high proton leakage in the warm contribute to insufficient oxygen supply (B). Maximum scope in ATP generation at the upper Tp supports an asymmetric performance curve of the whole organism (D). As a trade-off in eurythermal cold adaptation contrasting changes in exercise capacity versus those in growth rate are indicated by arrows in D (for further explanations see text).

tional challenge to ration energy intake during the short Antarctic summer in order to make a pelagic existence energetically feasible. These pelagic forms developed extensive energy saving strategies (neutral buoyancy through incorporation of lipids and extensive lipid deposits, reduced ion exchange activities, reduced calcification of the skeleton, reduction of bones, and morphometric parameters such as gill raker, fin and body sizes, De Vries and Eastman, 1981; Eastman and DeVries, 1982; Eastman, 1985; Andriashev, 1985; Ekau, 1988; Kunzmann and Zimmermann, 1992; Dorrien, 1993) to 

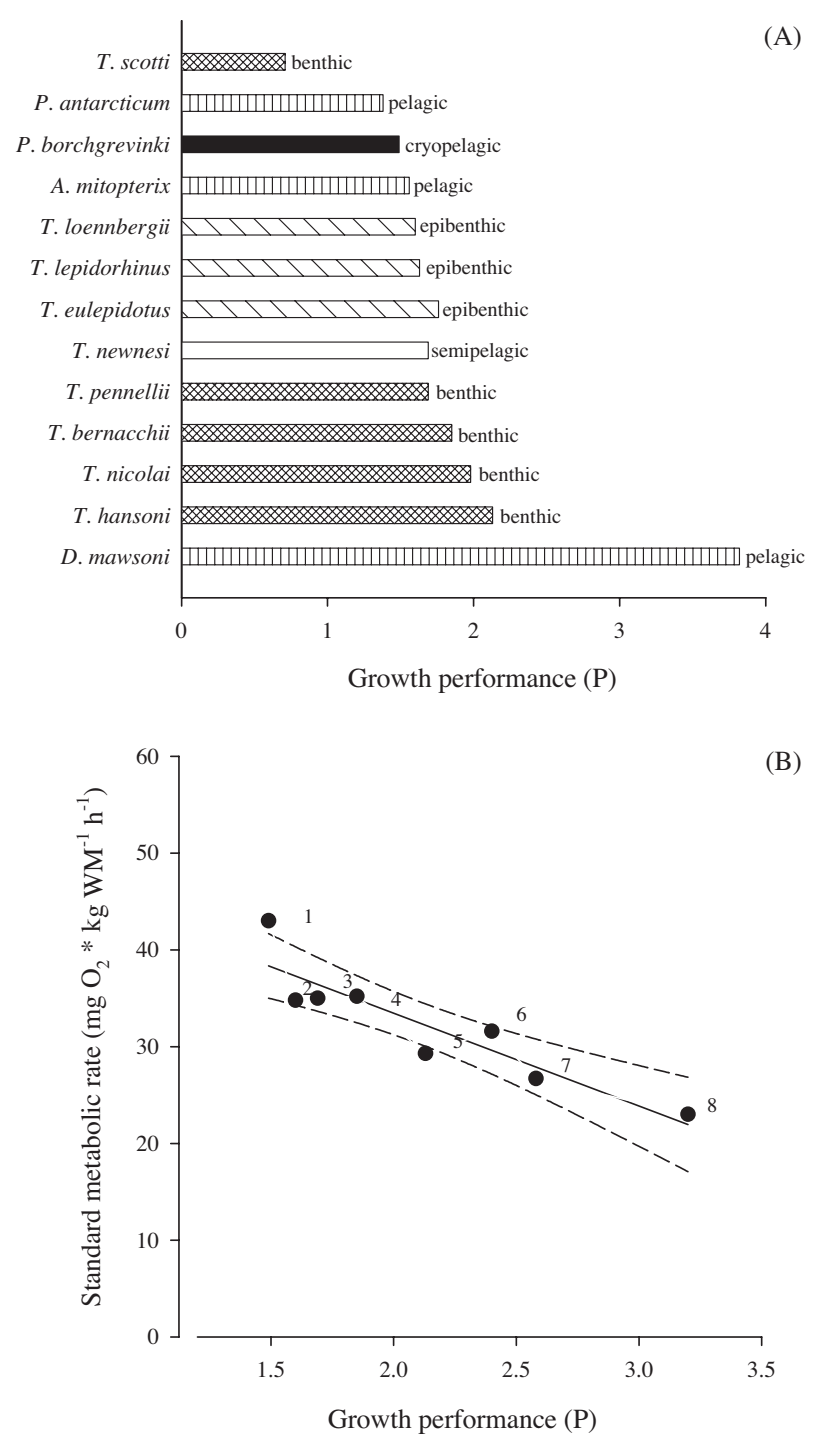

FIG. 2. - Overall growth performance $(P)$ of notothenioid fish in relation to (A) their mode of life in the high Antarctic zone and (B) their standard metabolic rate (SMR) in the high Antarctic and lesser-Antarctic/Subantarctic zone. According to Pauly (1979) overall growth performance $P\left(=\log \mathrm{K}+\log \mathrm{M}_{\infty}\right)$ describes the growth rate at the point of inflection of the size (mass) growth curve (K, year ${ }^{-1}$, is a measure of how fast fish attain their final size and $\mathrm{M}_{\infty}$ is the infinite mass of the fish, in $\mathrm{g}$ ). (A) Graph redrawn using $\mathrm{P}$ values compiled by La Mesa and Vacchi (2001). (B) P values by La Mesa and Vacchi (2001) and Hubold (1991), SMR: Holeton (1970), Forster $e t$ al. (1987), Johnston et al. (1991); Johnston and Battram (1993); Macdonald et al. (1988); Wells (1987) in Montgomery and Wells (1993); Morris and North (1984) in Thurston and Gehrke (1993); Zimmermann and Hubold (1998); Steffensen (2002); SMR values correspond to resting or standard metabolic rates, all expressed as $\mathrm{mg} \mathrm{O}_{2} \mathrm{~kg} \mathrm{WM}^{-1} \mathrm{~h}^{-1}$ (WM = wet mass) calculated for a $100 \mathrm{~g}$ fish at temperatures close to freezing. SMR values of one species from various citations were summarised to one mean. Linear regression: $y=-9.6 x+52.6(r=0.91)$; dashed lines indicate the $95 \%$ confidence interval. High-Antarctic species are: 1 Pagothenia borchgrevinki (cryopelagic, active under sea ice), 2 Trematomus loennbergii (demersal), 3 T. pennellii (demersal), 4 T. bernacchii (demersal), 5 T. hansoni (demersal), Lower- to Subantarctic species: 6 Notothenia neglecta (benthopelagic), $7 \mathrm{~N}$. gibberifrons (benthopelagic), 8 N. rossii (benthopelagic).

eliminate the higher costs associated with their lifestyle, achieve lower SMRs and thus higher growth rates. However, they are evidently not as successful in this strategy as demersal fish (Fig. 2, Priede, 1985; Dorrien, 1993; Zimmermann and Hubold, 1998).

High growth rates going hand in hand with low SMRs are in line with the above hypothesis of a trade-off leading to low growth performance at higher exercise capacities and vice-versa. Such trade-offs may also explain the different growth performance values between Antarctic and Arctic fish. Most stenothermal Antarctic notothenioids, with the exception of the very small $\left(\mathrm{M}_{\infty}=37 \mathrm{~g}\right)$ Trematomus scotti $(\mathrm{P}=0.71)$ from the Weddell Sea and the exceptionally heavy $\left(\mathrm{M}_{\infty}>100 \mathrm{~kg}\right)$ Dissostichus mawsoni from the Ross Sea $(\mathrm{P}=4.01)$, display $P$ values of 1-3 (Kock and Everson, 1998; La Mesa and Vacchi, 2001). In contrast, Dorrien (1993) found low overall growth performance values of 0-1.5 in selected Arctic benthic fish species. This finding is in line with a higher level of eurythermy and thus baseline energy turnover in Arctic compared to Antarctic fish and agrees again with the suggested principle.

\section{Latitudinal growth patterns in pectinid bivalves}

The question arises whether similar trade-offs between growth rate and metabolic costs may prevail among invertebrates. A recent study by Heilmayer et al. (2004) investigated the overall growth performance of pectinid bivalves in a latitudinal cline.

With some exceptions, the general consensus in the literature is that bivalve molluscs from low latitudes grow more rapidly due to high ambient temperature, attain a smaller maximum size and have a shorter lifespan than do con-familial species from higher latitudes (Newell, 1964; Roy et al., 2000; Heilmayer et al., 2004). The relationship between scallop growth performance and latitude can be best described by a Gaussian model (Fig. 3, r ${ }^{2}=0.39$ ). Certainly, this relationship does not reflect a direct effect of geographic latitude, but of variables coupled to latitude and associated annual solar energy input such as water temperature affecting metabolism, and primary production, which affects food conditions.

Several studies in bivalves have emphasised that growth variations may be linked to various physiological components of growth, such as whole-animal metabolic rate (Widdows, 1978; Koehn and Shumway, 1982; Toro et al., 1996), the intensity of protein turnover (Hawkins et al., 1986; Hawkins and 
Day, 1996; Storch and Pörtner, 2003) and the efficiency of protein synthesis and deposition (Bayne and Hawkins, 1997; Bayne et al., 1999; Storch and Pörtner, 2003).

As found for other polar ectotherms (Brey and Clarke, 1993; Arntz et al., 1994; Peck, 2002), the Antarctic scallop (Adamussium colbecki) displays slow annual growth (Fig. 3) compared with temperate and tropical counterspecies. Similar to the patterns found in fish, a reduced metabolic rate as shown by Heilmayer and Brey (2003) for A. colbec$k i$ might imply enhanced growth performance as less energy is "wasted" on the basal metabolism (Bayne and Newell, 1983; Clarke, 1987). Such a pattern would be in line with the trade-off in energy budget discussed above.

Recently, the ratio of $P$-to-mean SMR was investigated as a proxy for growth efficiency in pectinids across latitudes (Heilmayer et al., 2004). This ratio reflects the fraction of metabolic energy channelled into somatic growth. In temperate bivalve molluscs, e.g. Mytilus edulis, individuals with low basal or standard metabolic requirements display comparatively higher growth rates (for details see Hawkins et al., 1989; Wieser, 1994; Hawkins and Day, 1996) and thus high $P$-to-mean SMR ratios. This principle also appears to be operative between species across latitudes. In pectinids, the general decrease in growth efficiency with rising temperature across latitudes, as shown in Figure 4, gives evidence that metabolic rates increase faster with temperature than does overall growth performance, possibly as a consequence of enhanced energy availability, maintenance cost or cost of growth. The temperature coefficients $\left(\mathrm{Q}_{10}\right)$ computed from the corresponding Arrhenius models exemplify this difference: within the $0-25^{\circ} \mathrm{C}$ temperature range $\mathrm{Q}_{10}$ of scallop metabolic rate is 2.97 , whereas overall growth performance changes more slowly with temperature $\left(\mathrm{Q}_{10}=\right.$ 1.12, Heilmayer et al., 2004). Accordingly, the between-species comparisons carried out for pectinids in a latitudinal cline support the hypothesis of a trade-off in energy budget in the permanent cold, with enhanced levels of energy efficiency and allocation to growth.

As a conclusion, trade-offs between growth, baseline energy turnover and the associated levels of agility or exercise capacity become apparent in macroscale comparisons between Arctic and temperate as well as Arctic and Antarctic fauna. They are also operative within Antarctic notothenioid fish (see above). For several groups, such as pectinids, it

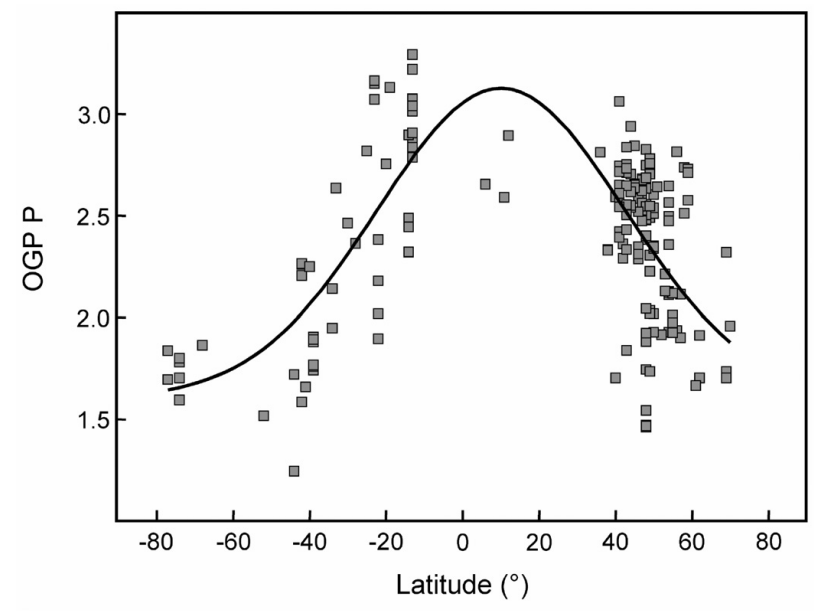

FIG. 3. - Relationship of overall growth performance $(P=\log \mathrm{K}+$ $\log \mathbf{M}_{\infty}$ ) and latitude of 198 populations of 26 scallop species (for references see Heilmayer 2003). Regression line:

$$
O G P P=1.6+\frac{123.5}{64.72 \sqrt{\frac{\Pi}{2}}} \cdot e^{\frac{-2(\text { Lat }-10.1)^{2}}{64.72^{2}}},\left(r^{2}=0.39 ; \mathrm{N}=198\right)
$$

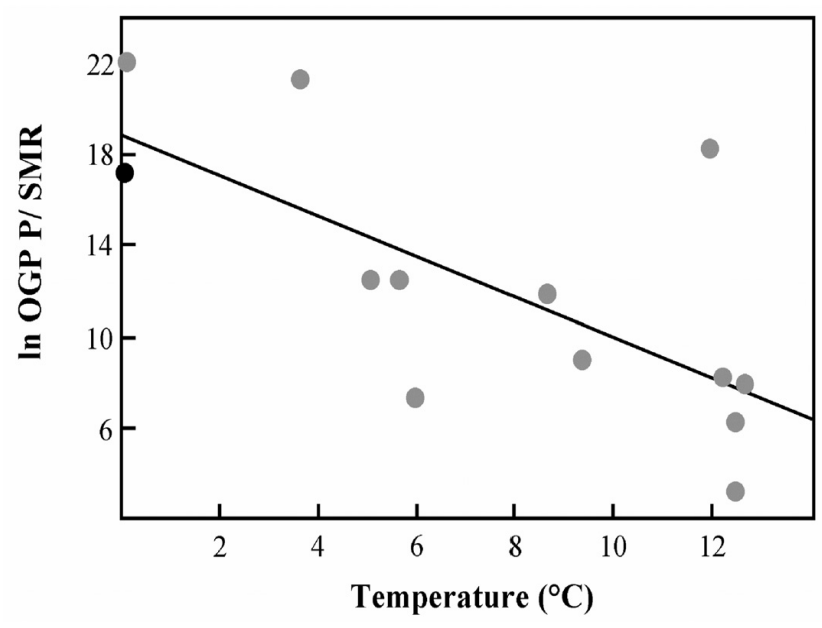

FIG. 4. - Relationship of the ratio of standard metabolic rate (mean $S M R)$ over growth performance $(P)$ to ambient temperature of 7 scallop species (grey dots: A. opercularis, $C$. islandica, $M$. varia, $M$, yessoensis, P. magellanicus, Z. patagonica; black dot: A. colbecki). Data presented are resting or standard metabolic rates at normal ambient temperatures. Where seasonal data were available the data were averaged for the whole year (for more details and references see Heilmayer et al., 2004). Regression line: OGP P/mean $\mathrm{SMR}=19.003-0.903 \mathrm{~T}\left(\mathrm{~N}=13, \mathrm{r}^{2}=0.496, \mathrm{p}<0.001\right)$

remains currently unclear to what extent this includes trade-offs in exercise capacity (Bailey et al., 2003). The principle similarity of such trade-offs may reflect a unifying principle by which, among species with similar lifestyles, those with a lower level of SMR, and thus lower baseline costs associated with a quieter mode of life, benefit from higher growth rates. 


\section{Protein synthesis capacity}

Growth and cellular functioning in tissues are closely related to protein synthesis and breakdown. Low rates of oxygen demand at low temperature therefore involve reduced protein turnover supported by reduced synthesis of highly complex protein systems like haemoglobin, ion pump systems, and possibly other protein complexes of basal metabolism (Clarke, 1991). The protein synthesis machinery will only be used for growth when excess energy in terms of food is available.

According to current understanding, annual growth of many polar species is low, but maximum growth rates in Antarctic stenotherms, invertebrates and fish can reach levels comparable to those found in the lower range for temperate species (Brey and Clarke, 1993; Arntz et al., 1994; Kock and Everson, 1998; Brodte, 2001; Peck, 2002).

In the light of these findings and of the observed energy savings in the cold, the protein synthesis machinery should be at least as energy-efficient as at warmer temperatures. At the same time protein synthesis capacity should not become limiting when food availability is high in polar summers despite cold temperatures. A recent analysis of the ATP cost of protein synthesis in temperate and polar pectinids demonstrated that the cost of protein synthesis remains unchanged regardless of temperature (Storch and Pörtner, 2003). However, high tissue RNA levels (commonly used as a measure of "protein synthesis capacity") have been observed in cold stenothermal invertebrates leading to increased RNA/protein ratios, which might imply a higher energy cost due to the cost of RNA synthesis (Whiteley et al., 1996; Robertson et al., 2001; Marsh et al., 2001; Fraser et al., 2002a). These high RNA levels have been interpreted to compensate for a cold-induced reduction in RNA translational efficiency in vivo (i.e. the extent to which capacity is used to synthesise protein per quantum RNA in vivo).

Increased RNA contents as seen in cold-adapted invertebrates have to be confirmed for fish and may simply be the result of low RNA turnover rates at no high cost. In fact, no difference in RNA content could be found in gill and muscle collected from Antarctic and North Sea eelpouts at their ambient temperatures. However, upon long-term acclimation from 0 to $5^{\circ} \mathrm{C}$, Antarctic eelpout showed a reduction in RNA levels, which would strengthen the hypothesis that RNA turnover rates influence the level of RNA, leading to a rise at low and a decrease at warm
Eelpout
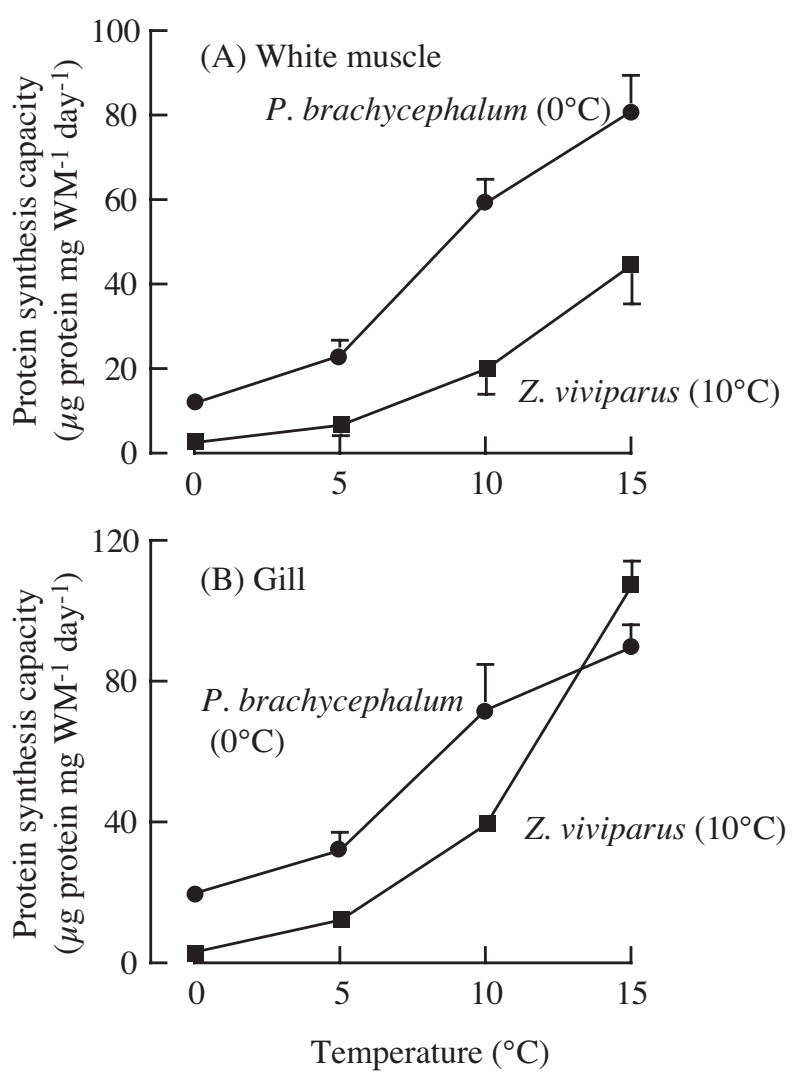

Pectinids

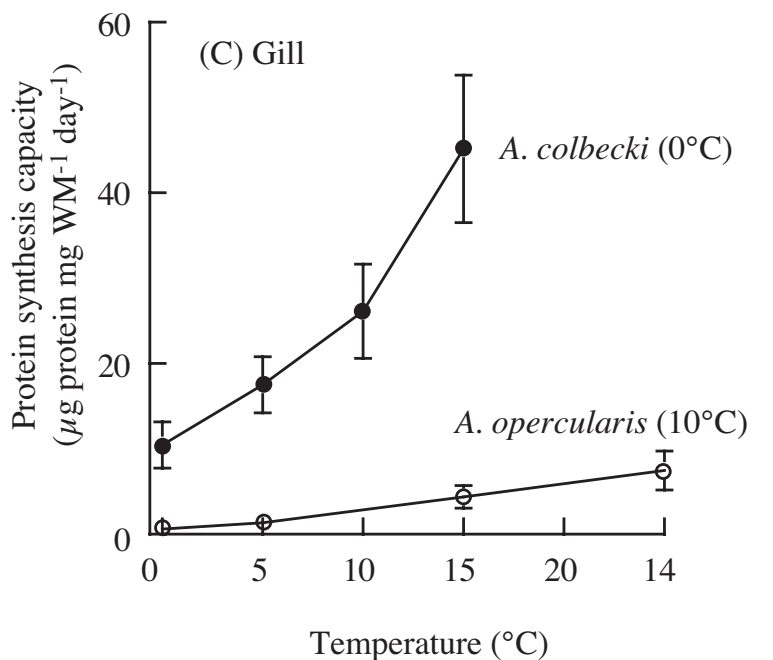

FIG. 5. - Cold compensation of in vitro protein synthesis capacities in Antarctic fish and invertebrates. Maximum rates were measured in tissue lysates at various temperatures and compared in (A) white muscle and (B) gills of Antarctic eelpout Pachycara brachycephalum acclimated to $0^{\circ} \mathrm{C}$ compared to temperate eelpout Zoarces viviparus acclimated to $10^{\circ} \mathrm{C}$. They are also compared in (C) gills of the Antarctic pectinid Adamussium colbecki acclimated to $0^{\circ} \mathrm{C}$ and of the temperate pectinid Aequipecten opercularis acclimated to $10^{\circ} \mathrm{C}$ (data adopted from Storch et al., 2003, 2005).

temperatures (Storch et al., 2005). Independent of RNA levels, the finding of high translational capac- 
ities at low temperatures indicates that the RNA translation apparatus is cold-compensated in invertebrates as well as in fish (Storch et al., 2003, 2005). All of these patterns would support enhanced functional capacities at maintained cost efficiency. Coldcompensated capacities of protein synthesis as found in white muscle and gills of Antarctic pectinids and eelpouts (Storch et al., 2003, 2005) are in line with the suggested trend in polar ectotherms to maximise growth performance at low baseline metabolic costs (Fig. 5).

It thus appears that growth capacity is cold-compensated in Antarctic stenotherms but this capacity may only be exploited during the short Antarctic summer. A capacity for the thermal adjustment of this process is evident in the Antarctic eelpout, in which protein synthesis capacity decreases during long-term acclimation from 0 to $5^{\circ} \mathrm{C}$ (Storch et al., 2005).

\section{GROWTH WITHIN ENERGY BUDGETS: ARE THERE UNIFYING PRINCIPLES?}

Growth is a complex process that is subject to controls and limitations at various levels. At first sight, an increase in SMR would indicate enhanced energy availability for growth. However, across phyla this may only be achieved at very high levels of energy turnover, as seen in cephalopods or mammals (cf. Pörtner, 2004). In the range of SMRs seen at low temperature or in hypometabolic fish and invertebrates, a high SMR apparently reflects high maintenance costs covered at the expense of growth. Studies within single invertebrate species led to the hypothesis that the primary physiological basis of an increase in production is reduced energy expenditure per unit of growth, indicating enhanced growth efficiency, rather than a straightforward increase in feeding and all other associated processes that are required for growth (Hawkins et al., 1986, 1989; Hawkins and Day, 1996; Schultz et al., 1996). According to the macroscale patterns discussed here, this principle is operative in ectotherms at high latitudes and probably reflects one major reason why Antarctic species are selected to minimize metabolic costs as much as lifestyle permits, at the expense of a high degree of stenothermy.

The trade-offs between energy turnover and growth in a latitudinal cline as depicted here were established in eastern Atlantic cod populations and for Antarctic fish as well as pectinids in a latitudinal cline. They also match observations of reduced growth capacities at increasing latitudes in anchoveta along the coast of Chile (Castro et al., 2001). For limnic large-mouth bass, modelling of energy allocation strategies also revealed that smaller size-atage occurs in the north than in the south, consistent with field patterns for this species (Garvey and Marschall, 2003). Further examples exist among fresh water fish.

However, as a note of caution, the trade-offs between growth rates and metabolic costs depicted here for cold-adapted low-activity fish and invertebrates may not easily explain all latitudinal growth patterns and energy allocation strategies observed. For example, growth capacity may not clearly differ between northwestern Atlantic cod populations in a latitudinal cline (Purchase and Brown, 2001), despite largely different temperatures. The growth patterns discussed and interpreted here also contrast higher growth capacities in northern than in southern populations of (North-American) silverside (Menidia menidia; Yamahira and Conover, 2002), which were suggested to compensate for the short growing season at high latitudes. This strategy is not apparently associated with different routine metabolic rates (Billerbeck et al., 2000). For these studies it would be interesting to further analyze the metabolic and energetic background of these apparently contrasting strategies in relation to temperature variability of specific environments. Explanations of potential differences between species or population-specific strategies for overcoming thermal and seasonal constraints require consideration of temperature means and climate variability (Pörtner et al., 2001) as well as the response to seasonal resource limitations (e.g. Hurst and Conover, 2003). The latter may also define seasonal changes in energy allocation (e.g. fattening strategies in autumn) and for cod, which were found to starve during winter in the Gulf of St. Laurence (Schwalme and Chouinard, 1999), may play a larger role on the western than the eastern side of the Atlantic.

Existing knowledge reviewed here leads to various lines of thought and testable hypotheses that might resolve these apparent discrepancies. It can be extrapolated from observations in Antarctic fish that cellular growth capacity can be fully compensated for the effect of low temperature. The level of standard metabolism will then decide whether such capacity can be fully exploited. For temperate species this pattern will depend on summer temperatures and low summer metabolic rates. This is in fact what is traditionally observed at temperate lati- 
tudes: summer temperatures support lower levels of temperature specific SMR than winter temperatures (e.g. van Dijk et al., 1999). Even in Subarctic (Barents Sea) cod there is such a trend. At $4^{\circ} \mathrm{C}$ SMR increases above the level seen at $4^{\circ} \mathrm{C}$ in North Sea cod, while at $10^{\circ} \mathrm{C} \mathrm{SMR}$ in the Barents Sea cod is reduced to almost the level seen in North Sea cod at $10^{\circ} \mathrm{C}$ (T. Fischer, R. Knust, H.O. Pörtner, unpubl.). This reduced "summer" SMR will then support high growth efficiency and maximised growth in Barents Sea cod, but still at rates below those of North Sea cod (Pörtner et al., 2001).

According to these patterns, it appears that due to high summer temperatures species populations exist at high northern hemisphere latitudes which are able to use efficient summer metabolic rates for maximised growth. Enhanced metabolic efficiency may even support a shift of growth capacity to above the rates seen at lower latitudes. There is very little information in support of this hypothesis and future work will have to test the relationship between SMR and growth in those species with maximised summer growth.

Despite these apparent exceptions, the present findings lead to answers for numerous discussions in the literature which suggested three basic explanations for slow annual growth rates at high latitudes:

1. The rate limiting effect of low temperature: This argument can probably be dismissed for the cellular level as it was recently shown for some cold-adapted stenotherms that a rate-limiting role for the ribosomal machinery at low temperature is alleviated by a large degree of compensation (e.g. Storch et al., 2003, 2005). Myogenic cell cycle duration also displays cold compensation (Brodeur et al., 2003). Future studies are needed to quantify the degree of growth compensation capacity at whole organism levels.

2. Seasonal activity: This explanation invokes no effect of temperature and has been a focal point for numerous studies regarding growth and seasonality at high latitudes in recent years. Polar regions allow the ecological effects of food to be distinguished from those of temperature since a greatly reduced seasonal variation in temperature coincides with enhanced seasonality of food availability (Clarke and Leakey, 1996; Brockington and Clarke, 2001). However, it has been argued that the seasonality of growth in Antarctic ectotherms is mediated through seasonal variations in resource utilisation rather than seasonal resource availability or temperature-dependent effects on growth (Coggan, 1997). Depending on feeding habits during winter, there were variable factorial rises in oxygen consumption from winter to summer in the Antarctic limpet Nacella concinna (x 1.6; Fraser et al., 2002b), the Arctic amphipod Monoporeia affinis (x 1.2; Lehtonen, 1996), the Antarctic infaunal bivalve Laternula elliptica (x 3; Brockington, 2001) and the Antarctic sea urchin $S$. neumayeri (x 2.5 to 3.1; Brockington and Peck, 2001). In S. neumayeri only $15-20 \%$ of the summerinduced increase in metabolism is explainable by the temperature increase, whereas $80-85 \%$ is caused by increased physiological activity associated with feeding, growth and spawning (Brockington and Clarke, 2001). While growth was found to fluctuate seasonally in Antarctic fish at South Georgia (North, 1998; North et al., 1998) and at Signy Island (Ashford and White, 1995), the former authors concluded that seasonal food resource limitation had a major effect, whereas Ashford and White (1995) could not find conclusive evidence for growth limitation either by sea water temperature or by resource availability. As a correlate of enhanced growth, however, "appetite" was higher under summer conditions.

Possibly, it is energetically not worthwhile to grow all year round but to restrict growth to a short period at the peak of food availability. Therefore, overall annual growth is slow but once growth is actually underway, it may proceed rapidly. In the meanwhile, hibernation patterns have been identified, largely in invertebrates and fish, associated with low energy turnover, low protein synthesis capacities and suspended growth during the Antarctic winter (Ashford and White, 1995; Lehtonen, 1996; North, 1998; North et al., 1998; Brockington, 2001; Brockington and Peck, 2001; Fraser et al., 2002a; Storch et al., 2003). The environmental triggers of hibernation are unclear, but some examples indicate that hibernation occurs with food available and may rather be due to a reduction of light and, to a minor extent, temperature. The use of hibernation strategies would thus explain the low average annual growth of Antarctic ectotherms. They may have been selected in response to low seasonal food availability and now support an energy saving stenothermal mode of life.

3. A rising cost of maintenance at the expense of a reduction in growth and reproduction: This argument considers the consequences of metabolic cold adaptation which may occur at the expense of growth (see above). In fact, metabolic cold compensation as seen in cold eurytherms would support enhanced levels of tissue energy turnover suitable 
for supporting spontaneous activity and exercise capacity at the expense of reduced growth (Pörtner, 2002b). Conversely, the degree of metabolic cold adaptation is minimal in stenotherms, so this explanation does not hold to explain reduced annual growth. As outlined above, the reduction in aerobic capacity and SMR in Antarctic stenotherms includes a reduction in baseline metabolic costs such that metabolic energy becomes available for enhanced and energy-efficient growth and reproduction processes in the permanent cold. In the light of relatively high peak summer growth rates, this leaves the seasonality argument (2) as the key explanation for slow annual growth in the Antarctic.

In summary, the energy budget hypothesis developed here and the suggested trade-offs between lifestyle, exercise and growth performance most consistently explain the patterns observed in stenotherms and in eurytherms in a latitudinal cline. These observations suggest that there probably exist hierarchies of energy allocation which clearly need to be studied. This should include the investigation of regulatory mechanisms involved in setting the fraction of the energy budget allocated to growth and other components of SMR (cf. Wieser, 1994).

\section{PERSPECTIVES: TRANSITIONS TO ANTARCTICA, PAST AND PRESENT}

So far the analysis has compared Antarctic and Arctic (including Subarctic) as well as temperate zone ectotherms. It has also emphasised that coldadapted eurytherms have largely been identified in the northern hemisphere, a phenomenon that may be linked to the more unstable temperatures at northern compared to southern latitudes. Considering the relatively stable temperatures at all latitudes of the southern hemisphere, the comparison of Subantarctic, Antarctic and Subarctic or Arctic species would make it possible to determine whether the evolution of marine Antarctic species occurred via a cold eurythermal intermediate form until the specialised cold stenothermal extant state was reached. Alternatively, the levels of energy turnover may be found lower at Subantarctic than at Subarctic latitudes, so a typical cold-adapted sub-polar eurytherm as found in the Subarctic may not exist in the south.

While studies of whole organism physiological patterns are underway in Magellan ectotherms ( $\mathrm{J}$. Calvo, personal communication) the patterns of mitochondrial metabolism depending on latitude
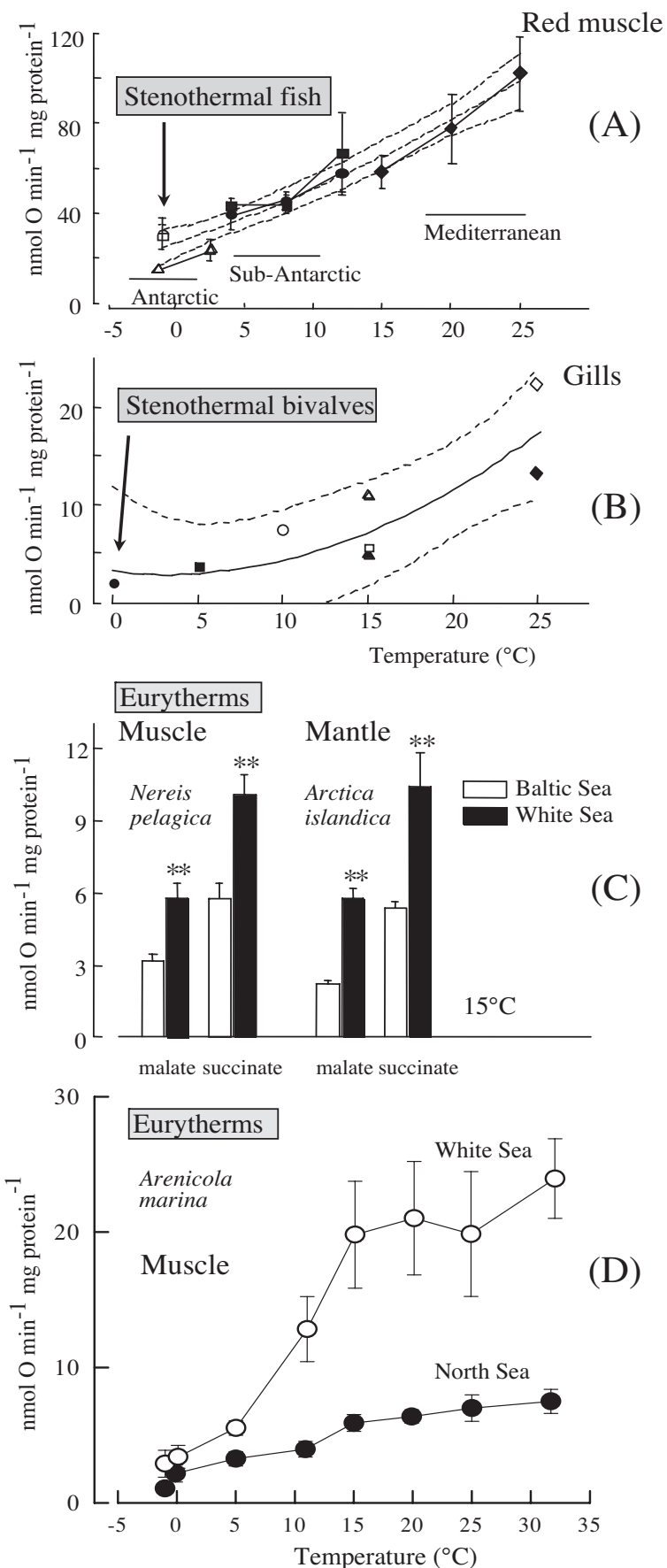

FIG. 6. - Mitochondrial ATP synthesis capacities (measured as state 3 respiration rates) in stenothermal and eurythermal ectotherms (adopted from Pörtner et al., 2000; Pörtner, 2004). (A) State 3 respiration rates at various temperatures of isolated mitochondria from red musculature of Antarctic (open symbols), Subantarctic (South American, filled circles and squares) and Mediterranean fish species (filled diamon, redrawn from Johnston et al., 1998). (B) State 3 respiration rates of mitochondria isolated from temperate and Antarctic bivalves and studied at various temperatures emphasize the down regulation of ATP synthesis capacities, similar to fish. (C) Elevated ATP synthesis capacities in mitochondria from White Sea compared to Baltic Sea populations of Nereis pelagica and Arctica islandica and from White Sea and North Sea populations of Arenicola marina (D) correlate with elevated proton leakage rates (Tschischka et al., 2000; Sommer and Pörtner, 2004).

Similar patterns were observed in a comparison of northeastern Arctic (Barents Sea) and North Sea cod (Gadus morhua) populations (T. Fischer, R. Knust, H.O. Pörtner, unpubl.). 
may provide a hypothesis for the metabolic transition to life in Antarctica. One basic insight from recent studies of metabolic cold adaptation is that for two species with the same moderate performance levels, the one with the colder body temperature needs more mitochondria / more mitochondrial enzymes for the same aerobic and thus functional capacity. Compared to other vertebrates, aerobic design in terms of mitochondrial densities is maximised in (pelagic) Antarctic fish, but cellular space constraints limit mitochondrial densities (Lindstedt et al., 1998). As a trade-off, mitochondrial proliferation is associated with a loss of contractile fibres and, thereby, maximum muscular force per unit muscular mass. The reduction in SMR is linked to minimised ATP synthesis capacities (determined as state 3 respiration) of mitochondria according to cold temperature (Fig. 6; Johnston et al., 1998). Available data indicate that in parallel to minimised ATP synthesis capacities in Antarctic stenotherms, mitochondrial proton leakage rates were also minimised in the cold (Pörtner et al., 1998, 1999b; Hardewig et al., 1999). Low leakage rates and thus low SMR indicate that these animals escaped from the cost of cold tolerance associated with an uncompensated loss of performance levels in the permanent cold.

These principle considerations can also be applied to eurytherms. However, seasonal cold acclimatisation and eurythermal cold adaptation to high sub-polar (northern) latitudes are associated with a compensatory rise in mitochondrial ATP synthesis capacities (Fig. 6), and finally organismic oxygen demand (standard metabolic rate). Rises in mitochondrial ATP synthesis capacity and in proton leakage reflect eurythermal cold adaptation (e.g. Tschischka et al., 2000; Sommer and Pörtner, 2002, 2004; T. Fischer, R. Knust, H.O. Pörtner, unpubl.). Cold tolerance at variable temperatures is therefore associated with enhanced costs of mitochondrial maintenance and associated high oxygen demand, as well as a high standard metabolic rate and high functional capacity.

As a generalised conclusion, eurytherms are exposed to the full cost associated with metabolic cold adaptation. This cost may be high because they need to make use of their mitochondria within the widest possible range of short-term ambient temperature fluctuations. As a precondition, the metabolic increase elicited by rising temperature must be kept small during short-term warming in order to maintain aerobic scope in the warm. In contrast to the sit- uation in stenotherms, this minimises the degree to which temperature-dependent kinetic barriers like high activation enthalpies can be established in molecular, cellular and systemic processes (Pörtner et al., 2000). Eurytherms may therefore choose to minimise mitochondrial densities and maximise ATP synthesis capacities instead (Fig. 6) in order to balance the cold-induced rise in baseline metabolic cost. The cost of cold adaptation is not only associated with proton leakage across the mitochondrial membrane, but also with ion movements (leakage) across the cellular membrane, which need to be compensated for by active ion exchange mechanisms (Pörtner et al., 1998). Accordingly, the densities and modulation of ion transport proteins also shape the cost of cold adaptation.

These largely contrasting patterns of cold adaptation observed in Antarctic marine stenotherms versus more eurythermal northern hemisphere coldadapted ectotherms emphasise that ambient temperature fluctuations play an important role in defining energy turnover. Accordingly, obligatory links very probably exist between the stability of (cold) climates and the level of energy demand. This principle insight can be applied to the mitochondrial data compiled by Johnston et al. (1998) for Mediterranean, Subantarctic and Antarctic fish (Fig. 6). Their data do not show any increase in mitochondrial capacities with falling temperatures, as would typify cold adapted eurytherms, but rather a progressive decrease occurs. The prediction results that the Subantarctic species, in terms of their mitochondrial capacities and in terms of their whole organism oxygen demand, fall onto a simple continuum between warm waters and the Antarctic. These patterns do not provide any evidence for a clearly eurythermal increase of mitochondrial capacity at Subantarctic latitudes. The patterns found rather mirror the more moderate temperature oscillations that characterise the sub-polar areas of the southern compared to those of the northern hemisphere.

On evolutionary time scales a similar conclusion arises in that moderate temperature oscillations during the long period of Antarctic cooling have not involved an obligatory transient expression of eurythermal, high-energy turnover life forms. Rather, notothenioid ancestors may have been pre-adapted to the extant notothenioid energy-saving mode of life, enabled and supported by moderate temperature oscillations and the resulting physiological features discussed here for stenotherms. These considerations demonstrate that the macro-scale comparisons 
of extant fauna from various latitudes, including comparisons between southern and northern hemispheres, appears to be an adequate tool for addressing and explaining the physiological bases of ecological patterns and, last not least, the pathways of climate-dependent animal evolution on earth.

\section{REFERENCES}

Abele, D., C. Tesch, P. Wencke and H.O. Pörtner. - 2001. How does oxidative stress relate to thermal tolerance in the Antarctic bivalve Yoldia eightsi? Antarct. Sci., 13: 111-118.

Andriashev, A.P. - 1985. A general review of the Antarctic bottom fish fauna. In: S.O. Kullander and B. Fernholm (eds.), Proc. 5th Cong. Eur. Ichthyol, Stockholm 1985, pp. 357-372. Department of Vertebrate Zoology, Museum of Natural History, Stockholm.

Arntz, W.E., T. Brey and V.A. Gallardo. - 1994. Antarctic zoobenthos. Oceanogr. Mar. Biol. Ann. Rev., 32: 241-304.

Ashford, J.R. and M.G. White. - 1995. An annual profile of growth in the otoliths of immature Notothenia coriiceps Richardson in relation to the environment at Signy Island, Antarctica. Antarct. Sci., 7: 345-349.

Bailey, D.M, L.S. Peck, C. Bock and H.O. Pörtner. - 2003. Highenergy phosphate metabolism during exercise and recovery in temperate and Antarctic scallops - an in vivo ${ }^{31} \mathrm{P}-\mathrm{NMR}$ study. Physiol. Biochem. Zool., 76: 622-633.

Bayne, B.L. and R.C. Newell. - 1983. Physiological energetics of marine molluscs. In: A.S.W. Saleuddin and K.M. Wilbur (eds.), The Mollusca. Volume 4: Physiology, Part 1, pp. 407-515. Academic Press.

Bayne, B.L. and A.J.S. Hawkins. - 1997. Protein metabolism, the costs of growth, and genomic heterozygosity: experiments with the mussel Mytilus galloprovincialis Lmk. Physiol. Zool., 70: 391-402.

Bayne, B.L., S. Svensson and J.A. Nell. - 1999. The physiological basis for faster growth in the Sydney rock oyster, Saccostrea commercialis. Biol. Bull., 197: 377-387.

Billerbeck J.M., E.T. Schultz and D.O. Conover. - 2000. Adaptive variation in energy acquisition and allocation among latitudinal populations of the Atlantic silverside. Oecologia, 122: 210-219.

Brey, T. - 1999. Growth performance and mortality in aquatic macrobenthic invertebrates. Adv. Mar. Biol., 35: 153-223.

Brey, T. - 2001. Population dynamics in benthic invertebrates. A virtual handbook. Version 01.2. WWW Page http://www.awibremerhaven.de/Benthic/Ecosystem/FoodWeb/Handbook/ main.html. Alfred Wegener Institute for Polar and Marine Research, Germany.

Brey, T. and A. Clarke. - 1993. Population dynamics of marine benthic invertebrates in Antarctic and Subantarctic environments: are there unique adaptations? Antarct. Sci., 5: 253-266.

Brockington, S. - 2001. The seasonal energetics of the Antarctic bivalve Laternula elliptica (King and Broderip) at Rothera Point, Adelaide Island. Polar Biol., 24: 523-530.

Brockington, S. and A.Clarke. - 2001. The relative influence of temperature and food on the metabolism of a marine invertebrate. J. Exp. Mar. Biol. Ecol., 258: 87-99.

Brockington, S. and L.S. Peck. - 2001. Seasonality of respiration and ammonium excretion in the Antarctic echinoid Sterechinus neumayeri. Mar. Ecol.-Prog. Ser., 219: 151-168.

Brockington, S., A. Clarke and A.L.G. Chapman. - 2001. Seasonality of feeding and nutritional status during the austral winter in the Antarctic sea urchin Sterechinus neumayeri. Mar. Biol., 139: $127-138$

Brodeur, J.C., J. Calvo, A Clarke and I. A. Johnston. - 2003. Myogenic cell cycle duration in Harpagifer species with sub-Antarctic and Antarctic distributions: evidence for cold compensation. J. Exp. Biol., 206: 1011-1016.

Brodte, E. - 2001. Wachstum und Fruchtbarkeit der Aalmutterarten Zoarces viviparus (Linné) und Pachycara brachycephalum (Pappenheim) aus unterschiedlichen klimatischen Regionen. Diploma thesis Univ. Bremen.
Castro, L.R., A. Llanos, J. Blanco, E. Tarifeño, R. Escribano and M. Landaeta. - 2001. Influence of latitude variations in spawning habitat characteristics on the early life history traits of the anchoveta, Engraulis ringens, off northern and central Chile. GLOBEC Report, 16: 42-45.

Chapelle, G., L.S. Peck. - 1999. Polar gigantism dictated by oxygen availability? Nature, 399, 114-115.

Clarke, A. - 1987. The adaptation of aquatic animals to low temperatures. In: B.W.W. Grout and G.J. Morris (eds.), Effects of low temperatures on biological systems, pp 315-348. Edward Arnold, Baltimore MD.

Clarke, A. - 1991. What is cold adaptation and how should we measure it? Am. Zool., 31: 81-92.

Clarke A. - 1993. Seasonal acclimatization and latitudinal compensation in metabolism: do they exist? Funct. Ecol., 7: 139-149.

Clarke, A. - 1998. Temperature and energetics: an introduction to cold ocean physiology. In: H.O. Pörtner and R. Playle (eds.), Cold ocean physiology, pp. 3-30. University Press, Cambridge.

Clarke, A. - 2003. Costs and consequences of evolutionary temperature adaptation. Trends Ecol. Evol., 18: 573-581.

Clarke, A. and R.J.G. Leakey. - 1996. The seasonal cycle of phytoplankton, macronutrients, and the microbial community in a nearshore Antarctic marine ecosystem. Limnol. Oceanogr., 41: 1281-1294.

Clarke, A. and I.A. Johnston. - 1996. Evolution and adaptive radiation of Antarctic fishes. Trends Ecol. Evol., 11: 212-218.

Clarke, A. and N. Johnston. - 1999. Scaling of metabolic rate and temperature in teleost fish. J. Anim. Ecol., 68: 893-905.

Coggan, R. - 1997. Growth: Ration relationships in the Antarctic fish Notothenia coriiceps Richardson maintained under different conditions of temperature and photoperiod. J. Exp. Mar. Biol. Ecol., 210: 23-35.

De Vries, A.L. and J.T. Eastman. - 1981. Physiology and ecology of notothenioid fishes of the Ross Sea. J. R. Soc. NZ, 11: 329-340.

Dorrien, C.v. - 1993. Ecology and respiration of selected Arctic benthic fish species. Ber. Polarforsch., 125: 1-104.

Eastman, J.T. - 1985. The evolution of neutrally buoyant notothenioid fishes: Their specializations and potential interactions in the Antarctic marine food web. In: W.R. Siegfried, P.R. Condy, R.M. Laws (eds.), Antarctic nutrient cycles and food webs, pp. 430-436, New York, NY, USA: Springer Verlag.

Eastman, J.T. and A.L. De Vries. - 1982. Buoyancy studies of notothenioid fishes in McMurdo Sound, Antarctica. Copeia, 2: 385-393.

Ekau, W. - 1988. Ecomorphology of nototheniid fish from the Weddell Sea, Antarctica. Ber. Polarforsch., 51: 1-140.

Forster, M.E., C.E. Franklin, H.H. Taylor and W. Davison. - 1987. The aerobic scope of an Antarctic fish Pagothenia borchgrevinki and its significance for metabolic cold adaptation. Polar Biol., 8: 155-159.

Fraser, K.P.P, A. Clarke and L.S. Peck. - 2002a. Low-temperature protein metabolism: seasonal changes in protein synthesis and RNA dynamics in the Antarctic limpet Nacella concinna Strebel 1908. J. Exp. Biol., 205: 3077-3086.

Fraser, K.P.P., A. Clarke and L.S. Peck. - 2002b. Feast and famine in Antarctica: seasonal physiology in the limpet Nacella concinna . Mar. Ecol.-Prog. Ser., 242: 169-177.

Frederich, M. and H.O. Pörtner. - 2000. Oxygen limitation of thermal tolerance defined by cardiac and ventilatory performance in the spider crab Maja squinado. Am. J. Physiol., 279: R1531R1538.

Garvey, J.E. and E.A. Marschall. - 2003. Understanding latitudinal trends in fish body size through models of optimal seasonal energy allocation. Can. J. Fish. Aquat. Sci., 60: 938-948.

Gaston, K.J. and S.L. Chown. - 1999. Why Rapoport's rule does not generalise. Oikos, 84: 309-312.

Guderley, H., J. St Pierre, P. Couture and A.J. Hulbert. - 1997. Plasticity of the properties of mitochondria from rainbow trout red muscle with seasonal acclimatization. Fish Physiol. Biochem., 16: $531-541$.

Hardewig, I., L.S. Peck and H.O. Pörtner. - 1999. Thermal sensitivity of mitochondrial function in the Antarctic notothenioid, Lepidonotothen nudifrons. J. Comp. Physiol. B, 169: 597-604.

Hardewig, I., P.L.M. van Dijk, C.D. Moyes and H.O. Pörtner. 1999. Temperature-dependent expression of cytochrome c oxidase in fish: A comparison between temperate and Antarctic eelpout. Am. J. Physiol., 277: R508-R516.

Hawkins, A.J.S. and A.J. Day. - 1996. The metabolic basis of 
genetic differences in growth efficiency among marine animals. J. Exp. Mar. Biol. Ecol., 203: 93-115.

Hawkins, A.J.S., B.L. Bayne and A.J. Day. - 1986. Protein turnover, physiological energetics and heterozygosity in the blue mussel, Mytilus edulis: the basis of variable age-specific growth. Proc. R. Soc. Lond. B, 229: 161-176.

Hawkins, A.J.S., J. Widdows and B.L. Bayne. - 1989. The relevance of whole-body protein metabolism to measured costs of maintenance and growth in Mytilus edulis. Physiol. Zool., 62: 745-763.

Heilmayer, O. - 2003. Environment, adaptation and evolution: Scallop ecology across the latitudinal gradient, $\mathrm{PhD}$ thesis, 147 pp., Universität Bremen, Bremen, Germany. http://elib.suub.uni-bremen.de/publications/dissertations/EDiss679_heilm.pdf.

Heilmayer, $\bar{O}$. and T. Brey. - 2003. Saving by freezing? Metabolic rates of Adamussium colbecki in a latitudinal cline. Mar. Biol., 143: $477-484$

Heilmayer, O., T. Brey and H.O. Pörtner. - 2004. Growth efficiency and temperature in scallops: Lessons from empirical data. Funct. Ecol., 18: 641-647.

Hochachka, P.W. and G.N. Somero. - 2002. Biochemical adaptation: Mechanism and process in physiological evolution. Oxford University Press, Oxford.

Holeton, G.F. - 1970. Oxygen uptake and circulation by a hemoglobinless Antarctic fish (Chaenocephalus aceratus Lonnberg) compared with three red-blooded Antarctic fish. Comp. Biochem. Physiol., 34: 457-471.

Holeton, G.F. - 1974. Metabolic cold adaptation of polar fish: fact or artefact? Physiol. Zool., 47: 137-152.

Hubold, G. - 1991. Ecology of notothenioid fish in the Weddell Sea. In: G. Di Prisco, E. Pisano and A. Clarke (eds.), Fishes of Antarctica. A biological overview, pp. 3-22, Springer-Verlag, Milano, Italia.

Hurst, T.P. and D.O. Conover. - 2003. Seasonal and interannual variation in the allometry of energy allocation in juvenile striped bass. Ecology, 84: 3360-3369.

Johnston, I.A., A. Clarke and P. Ward, - 1991. Temperature and metabolic rate in sedentary fish from the Antarctic, North Sea and Indo-West Pacific Ocean. Mar. Biol., 109: 191-195.

Johnston, I.A. and J. Battram. - 1993. Feeding energetics and metabolism in demersal fish species from Antarctic, temperate and tropical environments. Mar. Biol., 115: 7-14.

Johnston, I.A., J. Calvo, H. Guderley, D. Fernandez and L. Palmer. - 1998. Latitudinal variation in the abundance and oxidative capacities of muscle mitochondria in perciform fishes. J. Exp. Biol., 201: 1-12.

Kock, K.H. and I. Everson - 1998. Age, growth and maximum size of Antarctic notothenioid fish - revisited. In: G. Di Prisco, E. Pisano and A. Clarke (eds.), Fishes of Antarctica. A biological overview, pp. 29-40. Springer-Verlag, Milano, Italia.

Koehn, R. and S.E. Shumway. - 1982. A genetic/physiological explanation for differential growth rate among individuals of the American oyster Crassostrea virginica. Mar. Biol., 3: 35-42.

Kunzmann, A. and C. Zimmermann. - 1992. Aethotaxis mitopteryx, a high-Antarctic fish with benthopelagic mode of life. Mar. Ecol.-Prog. Ser., 88: 33-40.

La Mesa, M. and M. Vacchi. - 2001. Review. Age and growth of high Antarctic notothenioid fish. Antarct. Sci., 13: 227-235.

Lannig, G., L. Eckerle, I. Serendero, F.J. Sartoris, T. Fischer, R. Knust. T. Johansen, and H.O. Pörtner. - 2003. Temperature adaptation in eurythermal cod (Gadus morhua): comparison of mitochondrial enzyme capacities in boreal and Arctic populations. Mar. Biol., 142: 589-599.

Lehtonen, K.K. - 1996. Ecophysiology of the benthic amphipod Monoporeia affinis in an open-sea area of the northern Baltic Sea: Seasonal variations in body composition, with bioenergetic considerations. Mar. Ecol.-Prog. Ser., 143: 87-98.

Lindstedt, S.L., T. McGlothlin, E. Percy and J. Pifer. - 1998. Taskspecific design of skeletal muscle: balancing muscle structural composition. Comp. Biochem. Physiol. B., 120: 35-40.

MacDonald, J.A., J.C. Montgomery and R.M.G. Wells. - 1988. The physiology of McMurdo Sound fishes: current New Zealand research. Comp. Biochem. Physiol. B., 90: 567-578.

Marsh, A.G., R.E. Maxson Jr. and D.T. Manahan. - 2001. High macromolecular synthesis with low metabolic cost in Antarctic sea urchin embryos. Science, 291: 1950-1952.

Mitton J.B., C. Carey and T.D. Kocher. - 1986. The relation of enzyme heterozygosity to standard and active oxygen consumption and body size of tiger salamanders, Ambystoma tigrinum. Physiol. Zool., 59: 574-582.

Montgomery, J.C. and R.M.G. Wells. - 1993. Recent advances in the ecophysiology of Antarctic notothenioid fishes: metabolic capacity and sensory performance. In: J.C. Rankin and F.B. Jensen (eds.), Fish ecophysiology, pp. 342-374. Chapman and Hall, London.

Morris, D.J. and A.W. North. - 1984. Oxygen consumption of five species of fish from South Georgia. J. Exp. Mar. Biol. Ecol., 78 75-86.

Mueller, P. and J. Diamond. - 2001. Metabolic rate and environmental productivity: well provisioned animals evolved to run idle and fast. Proc. Natl. Acad. Sci. USA, 98: 12550-12554.

Newell, N.D. - 1964. Physiological variation in intertidal molluscs. In: K.M. Wilbur and C.M. Yonge (eds.), Physiology of molluscs, pp 59-87. I. Academic Press, New York.

North, A.W. - 1998. Growth of young fish during winter and summer at South Georgia, Antarctica. Polar Biol, 19: 198-205.

North, A.W., M.G. White and P.N. Trathan. - 1998. Interannual variability in the early growth rate and size of the Antarctic fish Gobionotothen gibberifrons (Lonnberg). Antarct. Sci., 10: 416-422.

Pauly, D. - 1979. Gill size and temperature as governing factors in fish growth: a generalization of von Bertalanffy's growth formula. Ber. Inst. Meereskd. Christian-Albrecht-Univ. Kiel, 63: $1-156$.

Peck, L.S. - 2002. Ecophysiology of Antarctic marine ectotherms: limits to life. Polar Biol., 25: 31-40.

Peck, L.S., A. Clarke and L.J. Holmes. - 1987a. Summer metabolism and seasonal changes in biochemical composition of the Antarctic brachipod Liothyrella uva (Broderip, 1833). J. Exp. Mar. Biol. Ecol., 114: 85-97.

Peck, L.S., A. Clarke and L.J. Holmes. - 1987b. Size, shape and distribution of organic matter in the Recent Antarctic brachiopod Liothyrella uva. Lethaia, 20(1): 33-40.

Peck, L.S. and L.Z. Conway. - 2000. The myth of metabolic cold adaptation: oxygen consumption in stenothermal Antarctic bivalves. In: E. Harper, J.D. Taylor and J.A. Crame (eds.), Evolutionary biology of the Bivalvia. Geological Society London, Special publications, 177: 441-450.

Peck, L.S., H.O. Pörtner and I. Hardewig. - 2002. Metabolic demand, oxygen supply and critical temperatures in the Antarctic bivalve, Laternula elliptica. Physiol. Biochem. Zool., 75: 123-133.

Peck, L.S., K.E. Webb and D. Bailey. - 2004. Extreme sensitivity of biological function to temperature in Antarctic marine species. Funct. Ecol., 18: 625-630.

Pörtner, H.O. - 2001. Climate change and temperature dependent biogeography: oxygen limitation of thermal tolerance in animals. Naturwissenschaften, 88: 137-146.

Pörtner, H.O. - 2002a. Climate change and temperature dependent biogeography: systemic to molecular hierarchies of thermal tolerance in animals. Comp. Biochem. Physiol. A, 132: 739-761.

Pörtner, H.O. - 2002b. Physiological basis of temperature dependent biogeography: tradeoffs in muscle design and performance in polar ectotherms. J. Exp. Biol., 205: 2217-2230.

Pörtner, H.O. - 2004. Climate variability and the energetic pathways of evolution: the origin of endothermy in mammals and birds. Physiol. Biochem. Zool., 77: 959-981.

Pörtner, H.O., R.K. O’Dor and D. MacMillan (eds.). - 1995. Physiology of cephalopod molluscs: lifestyle and performance adaptations. Gordon und Breach, Basel.

Pörtner, H.O. and S. Zielinski. - 1998. Environmental constraints and the physiology of performance in squids. S. Afr. J. Mar. Sci., 20: 207-221.

Pörtner, H.O., I. Hardewig, F.J. Sartoris and P. van Dijk. - 1998. Energetic aspects of cold adaptation: critical temperatures in metabolic, ionic and acid-base regulation? In: H.O. Pörtner and R. Playle (eds.), Cold Ocean Physiology, pp. 88-120. Cambridge University Press, Cambridge.

Pörtner, H.O., L. Peck, S. Zielinski and L.Z. Conway. - 1999a. Intracellular $\mathrm{pH}$ and energy metabolism in the highly stenothermal Antarctic bivalve Limopsis marionensis as a function of ambient temperature. Polar Biol., 22: 17-30.

Pörtner, H.O., I. Hardewig and L.S. Peck. - 1999b. Mitochondrial function and critical temperature in the Antarctic bivalve, Lat ernula elliptica. Comp. Biochem. Physiol. A, 124: 179-189. 
Pörtner, H.O., P.L.M. van Dijk, I. Hardewig and A. Sommer. 2000. Levels of metabolic cold adaptation: tradeoffs in eurythermal and stenothermal ectotherms. In: W. Davison, C. Howard-Williams and P. Broady (eds.), Antarctic ecosystems: models for wider ecological understanding, pp.109-122. Caxton Press, Christchurch New Zealand.

Pörtner, H.O., B. Berdal, R. Blust, O. Brix, A. Colosimo, B. De Wachter, A. Giuliani, T. Johansen, T. Fischer, R. Knust, G. Naevdal, A. Nedenes, G. Nyhammer, F.J. Sartoris, I. Serendero, P. Sirabella, S. Thorkildsen and M. Zakhartsev. - 2001 Climate induced temperature effects on growth performance, fecundity and recruitment in marine fish: developing a hypothesis for cause and effect relationships in Atlantic cod (Gadus morhua) and common eelpout (Zoarces viviparus). Cont. Shelf Res., 21: 1975-1997.

Pörtner, H.O., F.C. Mark and C. Bock. - 2004. Oxygen limited thermal tolerance in fish? Answers obtained by Nuclear Magnetic Resonance techniques. Resp. Physiol. Neurobiol., 141: 243-260.

Pörtner, H.O., M. Lucassen and D. Storch. - 2005. Metabolic biochemistry, an integrative view. In: J.F. Steffensen and A.P. Farrell (guest eds.), The physiology of polar fishes. To appear as volume 21 in the series Fish Physiology, W.S. Hoar, D.R. Randall and A.P. Farrell (series eds.).

Priede, I.G. - 1985. Metabolic scope in fishes. In: P. Tyler and P. Calow (eds.), Fish energetics: New perspectives., pp. 33-64. Croom Helm, London, Sydney.

Purchase, C.F. and J.A. Brown. - 2001. Stock-specific changes in growth rates, food conversion efficiencies, and energy allocation in response to temperature change in juvenile Atlantic cod. J. Fish Biol., 58: 36-52.

Ralph, R. and J.G.H. Maxwell. - 1977a. Growth of two Antarctic lamellibranchs: Adamussium colbecki and Laternula elliptica. Mar. Biol., 42: 171-175.

Ralph, R. and J.G.H. Maxwell. - 1977b. The oxygen consumption of the Antarctic limpet Nacella (Patinigera) concinna. Bull. Br. Antarct. Surv., 45: 19-23.

Robertson, R.F., A.J. El-Haj, A. Clarke, L.S. Peck and E.W. Taylor. -2001 . The effects of temperature on metabolic rate and protein synthesis following a meal in the isopod Glyptonotus antarcticus Eights (1852). Polar Biol., 24, 677-686.

Roy K., D. Jablonski, J.W. Valentine, and G. Rosenberg. -1998. Marine latitudinal diversity gradients: Tests of causal hypotheses. Proc. Natl. Acad. Sci. USA, 95: 3699-3702.

Roy K., D. Jablonski and K.K. Martien. - 2000. Invariant size-frequency distributions along a latitudinal gradient in marine bivalves. Proc. Natl. Acad. Sci. USA, 97: 13150-13155

Sartoris F.J., C. Bock and H.O. Pörtner. - 2003. Temperature dependent $\mathrm{pH}$ regulation in eurythermal and stenothermal marine fish: an interspecies comparison using ${ }^{31} \mathrm{P}-\mathrm{NMR} . J$. Therm. Biol., 28: 363-371.

Scholander, P.F., W. Flagg, V. Walters and L. Irving. - 1953. Climatic adaptation in arctic and tropical poikilotherms. Physiol. Zool. 26: 67-69.

Schultz, E.T., K.E. Reynolds and D.O. Conover. - 1996. Countergradient variation in growth among newly hatched Fundulus heteroclitus: geographic differences revealed by common-environment experiments. Funct. Ecol., 10: 366-374.

Schwalme, K. and G.A. Chouinard. - 1999. Seasonal dynamics of feeding, organ weights and reproductive maturation of Atlantic cod (Gadus morhua) in the southern Gulf of St. Lawrence. ICES J. Mar. Sci., 56: 303-319.

Sokolova, I.M. and H.O. Pörtner. - 2003. Metabolic plasticity and critical temperatures for aerobic scope in a eurythermal marine invertebrate (Littorina saxatilis, Gastropoda: Littorinidae) from different latitudes. J. Exp. Biol., 206: 195-207.

Sommer, A.M. and H.O. Pörtner. - 2002. Metabolic cold adaptation in the lugworm Arenicola marina: comparison of a North Sea and a White Sea population. Mar. Ecol.-Prog. Ser., 240: 171-182.

Sommer, A.M. and H.O. Pörtner. - 2004. Mitochondrial function in seasonal acclimatisation versus latitudinal adaptation to cold, in the lugworm Arenicola marina (L.) Physiol. Biochem. Zool., 77: $174-186$.

Steffensen, J.F. - 2002. Metabolic cold compensation of polar fish based on measurements of aerobic oxygen consumption: fact or artefact? Artefact! Comp. Biochem. Physiol. A, 132: 789-795.

Steyermark, A.C. -2002 . A high standard metabolic rate constrains juvenile growth. Zoology, 105: 147-151.

Storch, D. and H.O. Pörtner. - 2003. The protein synthesis machinery operates at the same expense in eurythermal and cold stenothermal pectinids. Physiol. Biochem. Zool. 76: 28-40.

Storch D., O. Heilmayer, I. Hardewig and H.O. Pörtner. - 2003. In vitro protein synthesis capacities in a cold stenothermal and a temperate eurythermal pectinid. J. Comp. Physiol. B, 173: 611-620.

Storch D., G. Lannig, H.O. Pörtner. - 2005. Temperature dependent protein synthesis capacities in Antarctic and temperate (North Sea) fish (Zoarcidae). J. Exp. Biol., 208: 2409-2420.

Thurston, R.V. and P.C. Gehrke. - 1993. Respiratory oxygen requirements of fishes: description of OXYREF, a data file based on test results reported in the published literature. In: R.C. Russo and R.V. Thurston (eds.), Fish toxicology, and water quality management. Proceedings of an International Symposium, pp. 95-108. Sacramento, California, USA, September 18-19, 1990.

Toro, J.E., A.M. Vergara and R. Gallegillos. - 1996. Multiple-locus heterozygosity, physiology and growth at two different stages in the life cycle of the Chilean oyster Ostrea chilensis. Mar. Ecol.-Prog. Ser., 134: 151-158.

Tschischka, K., D. Abele and H.O. Pörtner. - 2000. Mitochondrial oxyconformity and cold adaptation in the polychaete Nereis pelagica and the bivalve Arctica islandica from the Baltic and White Seas. J. Exp. Biol., 203: 3355-3368.

Urban, H.J. - 1998. Upper temperature tolerance of two Antarctic molluscs (Laternula elliptica and Nacella concinna) from Potter Cove, King George Island, Antarctic Peninsula. Ber. Polarforsch., 299: 230-236.

Vakily, J.M. - 1992. Determination and comparison of bivalve growth, with emphasis on Thailand and other tropical areas. ICLARM Tech. Rep., 36: 125 pp.

van Dijk, P.L.M., C. Tesch, I. Hardewig and H.O. Pörtner. - 1999. Physiological disturbances at critically high temperatures. A comparison between stenothermal Antarctic, and eurythermal temperate eelpouts (Zoarcidae). J. Exp. Biol., 202: 3611-3621.

Wells, R.M.G. - 1987. Respiration of Antarctic fish from McMurdo Sound. Comp. Biochem. Physiol. A, 88: 417-424.

Widdows, J. - 1978. Physiological indices of stress in Mytilus edulis. J. Mar. Biol. Ass. UK, 58: 125-142.

Whiteley, N.M., E.W. Taylor and A.J. El Haj. - 1996. A comparison of the metabolic cost of protein synthesis in stenothermal and eurythermal isopod crustaceans. Am. J. Physiol., 271: R1295-R1303.

Wieser ,W. - 1994. Cost of growth in cells and organisms: general rules and comparative aspects. Biol. Rev., 68: 1-33.

Wieser, W. and N. Medgyesy. - 1991. Metabolic rate and cost of growth in juvenile pike (Esox lucius L.) and perch (Perca fluviatilis L.): the use of energy budgets as indicators of environmental change. Oecologia, 87: 500-505.

Wohlschlag, D.E. - 1964. Respiratory metabolism and ecological characteristics of some fishes in McMurdo Sound, Antarctica. Antarct. Res. Ser. Amer. Geophys. Union, 1: 33-62.

Yamahira, K. and D.O. Conover. - 2002. Intra- vs. interspecific latitudinal variation in growth: adaptation to temperature or length of the growing season? Ecology, 83: 1252-1262.

Zielinski, S. and H.O. Pörtner. - 1996. Energy metabolism and ATP free-energy change of the intertidal worm Sipunculus nudus below a critical temperature. J. Comp. Physiol. B, 166: 492-500.

Zimmermann, C. and G. Hubold. - 1998. Respiration and activity of Arctic and Antarctic fish with different modes of life: a multivariate analysis of experimental data. In: G. Di Prisco, E. Pisano and A. Clarke (eds.), Fishes of Antarctica. A biological overview, pp. 163-174. Springer-Verlag, Italia. 
